\title{
Surgical Management of Pyometra in a Bitch - A Case Report
}

\author{
Nitin Soni $^{1 *}$, Rakesh Duggal ${ }^{2}$, Ajit Verma ${ }^{1}$, Pinki Rani', \\ Anand Kumar Pandey ${ }^{3}$ and Sandeep Kumar ${ }^{1}$
}

${ }^{1}$ Department of Veterinary Gynaecology \& Obstetrics, COVS, LUVAS, Hisar, Haryana, India

${ }^{2}$ Department of Animal Husbandry and Dairying, Haryana, India

${ }^{3}$ Department of Veterinary Clinical Complex, COVS, LUVAS, Hisar, Haryana, India

*Corresponding author

A B S T R A C T

\section{Keywords \\ Bitch, Pyometra, Ovario-hysterectomy \\ Article Info \\ Accepted: \\ 12 August 2018 \\ Available Online: \\ 10 September 2018}

\begin{abstract}
A five year old unspayed female Labrador dog weighing 28 kilogram was presented in Veterinary Clinical Complex, LUVAS, Hisar with a history of dehydration, uterine discharge, distended abdomen, vomition, anorexia, Anuria, inability to walk and pyrexia. On clinical examination, the rectal temperature was recorded as $104.3^{\circ} \mathrm{F}$, with swollen vulva and pus discharge. The bitch was treated with prostaglandins and antibiotics however, the bitch failed to respond the treatment. Based on the history, clinical observations, radiography and ultrasonography it was diagnosed as pyometra. Ovariohysterectomy was performed. The animal recovered uneventfully.
\end{abstract}

\section{Introduction}

Pyometra is the accumulation of pus within the uterine lumen, typically occurring during or immediately following a period of progesterone dominance.

The elevated progesterone levels help to create the ideal conditions for infection and stimulate uterine glandular secretions within the uterus, which suppresses uterine contractions (Cox, 1970) and inhibits the effect of fighting blood cells in the uterus. Canine pyometra is a common reproductive disorder of intact, diastrual bitch affects nearly one fourth of all female dogs before they reach ten year of age (Baithalu et al., 2010). The infection begins as an abnormal increase in the number of glands in the uterus. The secretions of these glands provide an excellent environment for bacteria that enter the uterus from the vagina. Once the uterus is infected, it can become filled with purulent material and progress to become a life threatening condition.

\section{Case History and Observations}

A 5 year old Labrador bitch, previously 2 times whelped was presented to the VCC, Hisar with the history of dehydration, uterine discharge, distended abdomen, vomition, anorexia, polyuria, inability to walk and pyrexia. On clinical examination, the animal appeared dull with $104.3^{0} \mathrm{~F}$ fever, pulse and 
respiratory rate were $97 / \mathrm{min}$ and $62 / \mathrm{min}$ respectively, swollen vulva and pus discharge. Haematological examination revealed reduced haemoglobin $(7.8 \mathrm{~g} / \mathrm{dl})$ levels with increased neutrophills $(82 \%)$.

\section{Treatment and Discussion}

Initially, it was decided to give a therapy for pyometra with inj. Lutalyse (Dinoprosttromethamine@ $0.2 \mathrm{mg} / \mathrm{kg}$ bw s/c twice daily for 3 days), inj. Ceftiforce SB $625 \mathrm{mg} @ 10 \mathrm{mg} / \mathrm{kg}$ bwi/m twice daily) along with supportive therapy (Inj. NSS $500 \mathrm{ml}$, I/V along with inj. Eldervet $2 \mathrm{ml}, \mathrm{I} / \mathrm{V}$ ) for 3 days, but no significant improvement on health was seen, so ovario-hysterectomy was performed under general anaesthesia as per standard procedure.

Antiseptic dressing of the surgical wound was carried out along with antibiotic and supportive therapy (Inj. Melonex $2 \mathrm{ml}, \mathrm{I} / \mathrm{M}, 3$ days; Syp. Polybion $5 \mathrm{ml}$, bid, PO, 15 days and Inj. DNS 5\% $500 \mathrm{ml}, \mathrm{I} / \mathrm{V}, 3$ days). The animal had uneventful recovery.

\section{Photograph showing large sized uterus with pus after exteriorization through caudal midventral abdominal incision}

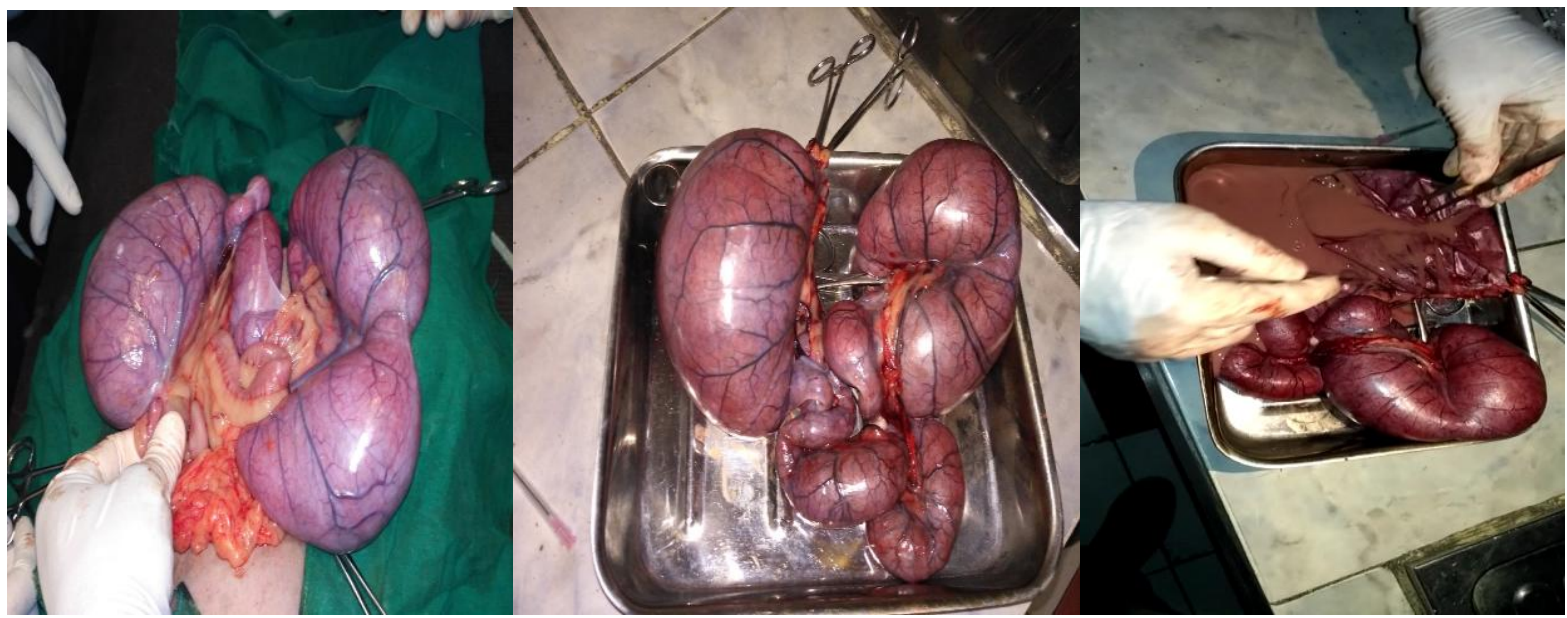

Pyometra is typically a post-oestral syndrome in adult bitches associated with a variety of clinical and pathological manifestations of genital and multi-systemic disease. It is postulated that intrauterine bacteria, which ascend from the vagina during pro-oestrus and oestrus, induce the disease during metoestrus by acting on the progesteroneprimed endometrium directly via toxin production, or indirectly by the release of inflammatory mediators (Noakes et al., 2001). The commonest clinical signs associated with pyometra include vaginal discharge, lethargy, polyuria, polydipsia, emesis and hyperthermia followed by hypothermia (Verstegen, 2006). The animal presented to hospital also exhibited similar symptoms. The presence of a vaginal discharge allows for a distinction between open and closed pyometra. The present case did not show complete recovery with medical treatment which could be attributed to voluminous pus present in the uterus. Singh et al., (2008) opined that medical management of canine pyometra is successful in early stages and ovariohysterectomy is choice of treatment in late phases of pyometra (Roberts, 1971).

\section{References}

Baithalu, R.K., Maharana, B.R., Mishra, C., Sarangi, L. and LipismitaSamal, L. 
2010. Canine Pyometra. Vet. World. 3(7): 340-342.

Cox, J.E. 1970. Progestagens in bitches: A review. J. Small Anim. Prac. 11: 759.

Noakes, D.E., Dhaliwal, G.K. and England, G.C. 2001. Cystic endometrial hyperplasia/pyometra in dogs: a review of the causes and pathogenesis. J. Reprod. Fertil. 57: 395-406.

Robert, S.J. 1971. Infertility in bitches and queens. Veterinary Obstetrics and
Genital Diseases. 2nd edn., (CAB Publisher and Distributors, India.,). pp. 227-236.

Singh, K.P., Singh, B.K., Singh, B., Singh, J.P., Singh, P. and Singh, H.N. 2008. Pyometra in bitches two case reports. Intas. Polivet. 9(2): 99.

Verstegen J, Karine 2006. Pyometra in the bitch and queen. Proceedings of North American Veterinary Conference. 20: 711.

\section{How to cite this article:}

Nitin Soni, Rakesh Duggal, Ajit Verma, Pinki Rani, Anand Kumar Pandey and Sandeep Kumar. 2018. Surgical Management of Pyometra in a Bitch - A Case Report. Int.J.Curr.Microbiol.App.Sci. 7(09): 1714-1716. doi: https://doi.org/10.20546/ijcmas.2018.709.207 